\title{
From the Family to the State: Shifts in Manchukuo Female Education Principles (1932-1945)
}

\author{
Wenwen Wang \\ Department of Integrated Sciences for Global Society, Kyushu University, Fukuoka, Japan
}

Email address:

wangwenwen213@yahoo.co.jp

\section{To cite this article:}

Wenwen Wang. From the Family to the State: Shifts in Manchukuo Female Education Principles (1932-1945). Education Journal. Vol. 8, No. 2, 2019, pp. 57-62. doi: 10.11648/j.edu.20190802.13

Received: February 6, 2019; Accepted: March 21, 2019; Published: April 18, 2019

\begin{abstract}
In 1931 Japan occupied northeast China, and in 1932 created a puppet state which they named "Manchukuo". The Manchukuo government began to formulate education policy immediately after its creation. Over the period of the state's existence, Japanese occupiers adopted a changing set of educational systems to meet the changing demands of the colonial state. This study investigates the state's main female secondary education objectives and principles, in the context of the state's overall goals, dividing the era into three distinct periods. This study finds that while the idea of "Good wives and wise mothers" was used consistently throughout the era, the emphasis changed from more domestic and personal issues towards more public issues, including sacrifice for the good of the state, and an emphasis on strong ties with Japan. The image of an ideal woman changed from a more traditional, domestic one, towards one in which women were expected to take up some of the roles had traditionally been played by men.
\end{abstract}

Keywords: Female Education, Manchukuo, Principle, Colonial

\section{Introduction}

In 1931, the Imperial Japan Army occupied the three provinces of Northeast China, and in 1932 created the puppet state "Manchukuo". 90\% of its population was Han Chinese. In order to justify its rule, the Manchukuo puppet government worked to reestablish and further develop the school system. Providing modern education, including education for girls, was one of the most significant ways the puppet government tried to claim legitimacy for its rule [1]. Over the course of the state's history, however, the Japanese occupiers changed the educational systems, to meet the changing demands of the colonial state.

Previous studies have drawn sketched out the outlines of Manchukuo education history. Qi Hongshen, who collected testimonies of Chinese who had been teachers or students in Manchukuo, found that one of the puppet regime's main interests was to create a Manchukuo national identity, separate from any Chinese national identity [2]. Yamamuro Shin'ichi emphasized the puppet nature of the Manchukuo state and describes the maneuverings among the participating Japanese and Chinese in their attempts to define what the
Manchukuo state would become [3]. Chinese historians Jiang Niandong and Yi Chengwen examined education in briefly in a comprehensive description of the history of Manchuria from its inception to its demise [4]. Du Yun compared and analyzed the features of normal education between Manchuria and Japan during this period. She pointed out that the countries had identical ideologies and policies on normal education, with the only difference being fewer classroom hours in Manchukuo [5].

While some scholarship has touched on female education, very few works have focused on it. There have been a few works on education for minority groups in Manchukuo. Liu Guobing studied female education in the Mongolian region of the country, and found that it closely resembled what the Manchukuo government in Han Chinese areas, especially in terms of Japanese language instruction [6]. Shimbo Atsuko also examined the education in the Mongolian regions, and found that while the Manchukuo government was able to increase the number of primary and secondary schools in the regions, but oversaw a decrease in the number of high school students and the quality of schools [7]. Hanai Miwa and Nakashima Takeshi analyzed female education for Koreas and Russians in Manchukuo, and emphasized how the 
government used Confucianism to teach proper roles for women [8-9]. Cai Yaqi, in her book about Manchukuo mobilization of females, focused on social education and women's groups, and touched only very briefly on the structure of education [10]. My earlier articles on the subject have provided a preliminary discussion on the changes in the quantity of Manchukuo women's schools in Han Chinese areas, as well as the textbooks and other curriculum issues. I have pointed out that there was a clear rise in female secondary students after the creation of a new school system in 1937, and female secondary education began to emphasize vocational education [11-12]. Examining morals textbooks used in the women's schools, I found that they worked to link women's family life with national interests [13].

In order to find the reality of Manchukuo female education, this paper aims to illuminate the puppet government's plans and purposes for female education. This is part of a larger project to determine what model for womanhood the Manchukuo government was creating. This includes how much educated women were encouraged to act outside the home, and what "ethnic harmony" was supposed to mean for them. In order to find the reality of the female education, this study uses articles published in Manchukuo education journals, and Manchukuo government documents. It examines the Manchukuo educators' main female secondary education objectives and principles over the course of different periods, working to understand those objectives in the context of overall government goals. These documents help explain the kind of roles the Manchukuo government and educators wanted to encourage for its female students, and the changing definition of the effort's main motto: "Good Wife and Wise Mother".

\section{Education Principles of Manchukuo (1932-1945)}

This paper will use the Manchuria education periodization developed by Wang Yeping, who divided the era into three stages: early colonial education (1932-1937), mature colonial education (1938-1940), and wartime colonial education (1941-1945)[14]. This study is using a slightly adjusted version of this periodization, dividing the era into 1932-1937, 1937-1942, and 1942-1945.

\subsection{Liberal Common Education Transformed into Narrow Restricted Education (1932-1937)}

To explain the state of Manchukuo female secondary education during the 1932-1937 period, there needs to be some explanation of the state of female secondary education in Manchuria before 1932. The Fengtian Female Normal School, in Fengtian Province, was one of the leading secondary schools in the region. An examination of a 1926 school handbook gives a glimpse of the school's leading principles before the Manchurian Incident. The handbook emphasizes a student-centered curriculum, in which teachers work to help the students express and prepare for their ambitions, develop their research ability, and take responsibility, thus imbuing them with "a spirit of selfreliance." [15] The school also emphasized honesty, cooperation, moral rectitude, and other personal virtues, as can be seen in the school song [16].

Our school teaches etiquette

Our principle is to keep evil away

And keep honesty in our hearts

Eschew lies, swear together to be honest

Be kind and polite

Self-cultivation, doing right

Holding big ambitions, being honest

Motivating ourselves, studying together

All levels of school (pre-school, elementary, and secondary) are based on this idea

We need to learn these morals

And keep them our whole lives

Teaching children these morals:

Diligent study and morality

Is our natural duty

The school did not emphasize gender differences, did not speak of special rules or objectives for girls, and did little to delineate a special curriculum for girls. The handbook did not emphasize teaching about women's domestic roles. The girls were expected to take their education and make their own futures. The Fengtian Female Normal School operated in the spirit of liberal education, which had gained popularity in China since the visit of the American educator John Dewey in 1919-1921.

After the Manchurian Incident in 1931, schools all over the region were disrupted or even closed. Although the Manchukuo government worked to reopen schools, the total number of girls in secondary education declined from 1932 to 1936.

Looking at writing on female secondary education in the years following the Manchurian Incident, there was a shift towards a greater focus on the specific roles of women as wives and mothers, and a greater emphasis on the authority of teachers. For example, in 1933 the administration of the Fengtian First Female Secondary School wrote an article for the magazine Fengtian Education, titled "Embodiments of Labor Education," which stated that girls' schools should provide content designed particularly for girls [17]. Female education should not just train talented people to serve society's public needs, but also cultivate future good mothers. It is said that females have particular roles within the family, and graduates who were ignorant about domestic duties would become unhappy with their education [17].

School education has two objectives: one is to train students to serve society; another is to train students' technology skills for the family, [an objective] which does not exist in the male schools. Because female schools have special relationship with the family, the education in female schools is always focused on the problems of practical life. Female students who cannot properly cook and sew after their graduation will blame the schools for not teaching them properly. So, does it have any value to educate students when 
the education is not effective?

This represents a clear change from the pre-Incident attitudes.

Bai Guangtian, who in 1935 was the director of the discipline in the Fengtian Female Normal School, said that female secondary education had two missions: to teach students to become good teachers and good mothers [18].

Female normal school education has two missions: one is to [teach students to] become good teachers whose upstanding morality will influence children, and the other one is to become good mothers who teach their children at home. In terms of society, education should train female students to become good teachers. They should be hardworking, firm, and have a spontaneous interest in public affairs. Second, in terms of the family, students should become "good wives and wise mothers" with a cheerful attitude, a healthy body, and an ability to deal with family affairs.

Liu Rongfu's 1935 article "Points for Special Attention on Practices and Methods in Current Manchukuo Female Education", said discipline was the most important thing in moral education [19]. "Discipline should pay attention to six aspects: 1) training females to be honest and to love their own country, 2) training them to become good wives and wise mothers, 3) helping females to improve themselves in overcoming their disadvantages, such as weakness, vanity, suspicion, etc., 4) providing a good direction on correct ideology; 5) training them to cultivate good work habits and 6) stressing the importance of vocational education for selfsufficiency" [19]. This article emphasized supposed female characteristics, both negative (weakness, vanity, suspicion, etc.), as well as positive (acting for the good for family, society, and the state). Liu ignored, however, developing qualities such as self-reliance or thinking for oneself, as had been emphasized in previous years.

A Manchukuo government official, referred to as "Section Chief Nawa", had an article in Fengtian Education in 1936 titled "The Essence of Female Education", in which he equated female education with "maternal education." $\mathrm{He}$ emphasized teaching women that females were naturally different from males, with their own unique instincts and characteristics which needed to be nurtured, which would contribute to their family's prosperity. He also mentioned how teaching "maternal education" played a crucial role in preserving the country [20]. This would be a foretaste of the greater emphasis on women's contributions to the state in the coming period.

Female education is to develop female instincts, and to promote the country's full development. ...In the ideology of old Asia, there is a saying that (the male) "Yang" is dividing, active, and creative, while (the female) "Yin" is unifying, hidden, and preserving. ... Before the world was established, male and female have already existed and were differentiated from each other. ... The "Yin" can supplement what the "Yang" lacks, and comfort "Yang" in his restlessness of "Yang". That is the mission of female. As Manchukuo was created through division, we now need deep, long-suffering power to protect the achievements. We cannot have a division between these two forces. ... This goes against the European idea of male-female equality.

In Fengtian before the Manchurian Incident, the objective of female secondary education was to train female students in a comprehensive and liberal way, not prescribing certain occupations or roles for them. However, during the period of 1932-1937, the rhetoric on female education changed from a focus on freedom and opportunities to one which was more limited and particular. The contents of moral education were transformed from teaching principles of individual morality into understanding female duties towards family and society. Female education was concentrated on training girls to become good teachers for society and "good wives and wise mothers" for the family. Females were regarded as a special group, who had special duties and functions. The scopes of female activities were largely narrowed to the school and home.

\subsection{Evolution from Limited Particular Education to Practical, Vocational, and Political Education (1937-1942)}

The first years of Manchukuo's existence was marked by instability and rebellion. By 1937 the state had stabilized, and the government did not face as many immediate threats. As a result, government officials had the room to begin long-term economic plans, beginning with the first 5-year plan, which was announced in January 1937. The plan included an ambitious plan for rapid industrialization, in close collaboration with Japan. The plan required higher number of educated, Japanese-speaking graduates from the schools. In response, the Manchukuo government in May 1937 announced a "New Education System", which reformed all Manchukuo education. Comparing the overall structure of the old and the new Manchukuo education systems, three main areas of secondary education were changed. First, because the minimum age of admittance to primary schools was lowered from age eight to age seven, and primary education was fixed at six years, the admission age of secondary schools also changed from age fourteen to thirteen. This means that the age of female students who entered the secondary schools was younger than before. Secondly, according to the "New Education System", the previously existing lower secondary schools and higher secondary schools, both of which were three year schools, were synthesized into a single level of schools named national high schools. The new schools were four-year schools, which shortened the total available secondary education by two years. The previous girls normal schools, such as the Fengtian Female Normal School, appear to have been closed in 1938, and replaced by a system where girls wishing to become an elementary school teacher would attend the girls' national high school for four years, and then attend a special normal course for one or two additional years [21]. After the Manchukuo government issued a "New education system" in 1937, the number of female secondary students increased, although the total number of schools did not rise [11]. 
This next section will continue to look at articles published in the education journal Fengtian Education, beginning with a special issue in December 1937 on the New Education System, helping teachers to prepare for the coming changes. They show that from 1938 to 1942 , female education changed its emphasis from duties to the family to duties to the wider society and state. Authors on education increasingly spoke of the need for females to learn patriotism. There were also continuities--authors continued to encourage teaching students to avoid "selfish" Western ideas, including individualism, materialism, and feminism.

\subsubsection{The Greater Public Good of Domestic Work}

In the 1932-1937 period, females were taught to succeed in their domestic efforts because doing so was good for the family. The reasoning was linked to traditional Confucian ideas of female duties to the extended family. In the 19371942 period, however, the importance of females' domestic efforts was linked to the greater national good. Females were to be "Good Wives and Wise Mothers" not only for the benefit of the family, but also for the benefit of society and the country as a whole.

The home was still considered to be the ideal place for women. Nakamura Toshiō wrote, "Females' natural mission is to go from a nurturing family to a school to gain an education, and then return to the family in the end" [22]. Their role in the home, however, was now considered to be for the benefit of the country. Satō Yoshiko wrote, "Family life is one of manifestations of national life. Family life can not deviate from national life, so the guiding spirit of family is same as the national spirit" [23].

Nakano Hideo pointed out knowledge of Manchukuo's "founding spirit" (the patriotic ideals which explained and justified the state's creation), and civic mindedness as two of the essentials of female education. "First, promote knowledge to understand "founding spirit". Second, cultivate a spirit of respecting work. Third, train to respect public health. Fourth, cultivate civic mindedness, and finally, understand reason and act with dedication" [24]. These authors saw females' domestic work as not just a private duty, but also as a public duty.

\subsubsection{Patriotism in Female Education}

Among the ideals Manchukuo females were encouraged to embrace was patriotism and knowledge of the state's founding. Authors frequently emphasized Manchukuo's "founding spirit" in their discussion of female education from 1937 to 1942.

Two December 1937 articles in Fengtian Education tied women's domestic efforts with national defense. Nakano listed three missions for females at home: "First, females should fully understand the "founding spirit" of Manchukuo. ... Second, females should cultivate the management of national defense and fulfill female duties on defense. ...Last, females should contribute to the state and join in the movement of improving daily life [24]." Similarly, Satō said "Female education is derived from family education ... the nourishment of families by females will develop national character and also contribute to human development ... Female education teaches females to understand their natural duties, improve the family, and take part in the completion of the sacred goal of 'Paradise of the Kingly way"" [23].

Another author said that the addition of national spirit education into the schools was a defining characteristic of Manchukuo education. "Education before the Manchuria Incident only imparted knowledge without any investigation on ethnic nature or environment... Such education without any national education trained students without personality or moral integrity ... After Manchukuo was founded, education clearly defined the "founding spirit". National education should follow the advice of the [1935] edict promulgated by our emperor and train nationals loyal to the country" [22]. This article also mentioned Manchukuo school education with its focus on the nation and the family as a corrective to the influence of Western missionary education.

After the reform of education in 1937, therefore, female education increasingly taught students to understand the state "founding spirit". They were expected to become mothers who would teach patriotism and loyalty to the state to their children.

\subsubsection{Criticism of Western Ideology and Advocating Eastern Virtues}

Although criticism of Western ideology in Manchukuo was not new in 1937, it seems that the criticism became especially frequent in this period. Some western ideas, such as individualism, materialism, and female liberation, were criticized as harmful to female students. They insisted that Eastern morality was more beneficial to females.

Satō Yoshiko, in a lecture on the school subject Zuoye (domestic affairs) for female primary school teachers in 1937, discussed how educated females could be misled by Western theories. "The objective of female education is to train females be 'good wives and wise mothers' ... The Western ideology of materialism, which says that males and females are equal and females need to be liberated, and which completely denies the female nature, has greatly influenced many females' outlook on life. ... It also has placed the nation in danger. ... Eastern family-centered society is not compatible with Western individualism. Females should return to the home, help the world understand the Eastern ideology of 'good wife and wise mother', and come to understand the principle of 'Family Harmony, State Governing and World Peace"' [23].

A 1937 article by Nakano Hideo said that Western ideas had ruined many females. "There are two extreme types of females: one type is weak and incompetent in daily life, influenced by common customs and don't have deep contact with the outside. ... Another type is harmed by ideas of gender equality. This group of female got the equal education as men, but they just enjoy themselves and never work" [24]. Likewise, a 1938 article by Nakamura Toshio criticized individualism and materialism for destroying the family and ignoring ethics [22]. 
Manchukuo authors not only blamed Western ideologies for damaging female thought, they blamed them for damaging the national spirit as well. A Chinese author named Ren Zhongxiao wrote in 1941, "In the Republic of China, Western thoughts, which advocated equality and freedom, greatly impacted females. Females would talk glibly about 'freedom and equality, male and female equal rights'.... They tried to make reforms, but instead their blind worship just led to odd mistakes. ...Every country has its own spirit and morality. Western thoughts damaged the national spirit, encouraging people to abandon our country's original spirit and morality without any introspection. ... Three bad results occurred in education: first, females (especially high school students) became arrogant; second, females never learned how to find a suitable male to marry; third, female changed after their marriage and could not use the knowledge they learned in school to build up their new families." Therefore, "Manchukuo female education should try to remove the bad thoughts from Europe and America, and instead try to meet the needs of society, by developing original female spirit [25]."

In the period of 1937 to 1942 Manchukuo educators considered Western concepts of freedom, equality, etc. were regarded as unsuitable for the East, and as the root cause of female weakness. They cherished and emphasized perceived Eastern virtues, such as a female's nature desire towards her family and children, feminine virtues, and diligence and patience. They saw it as their job to rectify "mistakes" made in past education.

From 1937 to 1942 there was a shift in female education rhetoric from an emphasis on traditional roles and the good of the family, towards celebrating the public benefit of wise mothering, an emphasis on patriotism, and a criticism of Western ideas.

\subsection{Country-centered Education (1942-1945)}

The Manchukuo government began to carry out the wartime system education when the Pacific War broke out. In December of 1942, the Manchukuo government issued two guiding documents: the "Basic National Principles" and "National Orders". Both documents spoke of the need for speeded-up industrialization, and the importance of education, especially vocational education, to achieve these goals. "The education and training of youths should emphasize cultivating the concept of the state. We should develop vocational education as a part of training students to be healthy and active new people" [14].

In 1943, owing to the worsening of the wartime situation, the Manchukuo government made amendments in secondary education. These changes can be seen in a comparison in the Education Acts of 1937 and 1942 (Table 1).

Table 1. The Education Act in 1937 and 1942 [26-27].

\begin{tabular}{lll}
\hline & Education Act in $\mathbf{1 9 3 7}$ & Education Act in 1942 \\
\hline Article I & $\begin{array}{l}\text { In order to cultivate moral qualities, we must place } \\
\text { special emphasis on education of the spirit. }\end{array}$ & $\begin{array}{l}\text { The purpose of our country's education is follow the emperor's edict and the "Way of } \\
\text { the Gods" (Shinto), train people with a filial spirit, show loyalty to the country, live } \\
\text { with charity and concord, and devotion for society. } \\
\text { Our goal for the country's education is to cultivate people with skills facing the needs } \\
\text { of country, and exercise their body and mind. It is a practical education, which faces } \\
\text { the people's daily life, training people to serve the country and be good at a vocation. }\end{array}$ \\
$\begin{array}{l}\text { Pay attention to practical education and try to } \\
\text { avoid education, which only focus on knowledge. }\end{array}$ & $\begin{array}{l}\text { Remove all the fixed ideas that thought education } \\
\text { just prepares students for the higher education. } \\
\text { Education should be complete at each level of the } \\
\text { school system. }\end{array}$ & $\begin{array}{l}\text { When we teach students, we should adapt to the characteristics of students and play } \\
\text { well on the different features of different courses, and train students to be national } \\
\text { people. Education could train students to become second-generation national citizens } \\
\text { in the future if education follows that principle. Each teacher should keep on trying. }\end{array}$ \\
\hline
\end{tabular}

Comparing the education acts in 1937 and 1943, there was a greater emphasis on serving the interests of the country. It can be seen that loyalty to the country and devotion were especially emphasized in 1943. By comparing the first item in 1937 and 1943, the item of 1943 gave more details about what kind of spirit should be transferred and what kind of people should be educated, not like the general concept of that in 1937. In 1943, the new education act requested education follow the emperor's edicts, in particular a shift to public reverence of Japanese Shinto deities. It also emphasized that education should cultivate a filial spirit, show loyalty to the country, live with charity and concord, and devotion for society.

Second, the knowledge delivered in school asked for more close relationship to real life and satisfied needs of the country. This was different from the education in 1937, which simply advocated a practical education, education in 1943 commanded students to learn more skills, face the needs of country and people's daily life, and exercise their body and mind.

Overall, a new turning point occurred in the female education in 1943. Education was closely connected with country and public society. Each education effort was performed around the needs of country and worked for the country's benefit.

\section{Conclusions}

Female secondary education mainly focused on three aspects to training female students as new "Good wives and wise mothers": 1) Modern science and technology education: the building of modern family under the wartime system, including the value of thrift. 2) Labor education. Under the wartime system, a female was trained to have a diligent ability and more professional skills to work for the national production. 3) Ideological education. Female education tried to encourage students to value the state and its ties to Japan.

Under the wartime system, a new concept of "Good wives 
and wise mothers" for female secondary education developed, based on the interests of the country and the needs of the war. The focus of female education continued to shift from family to country. For instance, the course of house economics was no longer training females how to increase the quality of life for the family as it did before but instead trained them how to save more resources for the country and society. What is more, the needs of the war caused the rhetoric to change in a way in which females were encouraged to find an occupation, not for their own personal fulfillment, but for the contribution they could make for the country. The people were being mobilized for war, and many men had left their positions to serve in the military. Women, therefore, were being asked to serve the state both by taking up some of the roles that men had played.

\section{Acknowledgements}

This work would not have been possible without the financial support of the China Scholarship Council. I am especially indebted to Dr. Andrew Hall who has provided insightful discussion.

\section{References}

[1] Duara, P. (2006). Nationalism, imperialism, federalism, and the case of Manchukuo: a response to Anthony Pagden. Common Knowledge, 12(1), 47-65.

[2] Qi H. S. (2004). Translated by Takenaka Kenichi, Manchuria oral history: resistance on "suffering education". Tokyo: Kosei Press, 230-249.

[3] Yamamuro S. (2006). Manchuria Under Japanese Dominion. University of Pennsylvania Press.

[4] Jiang N. D., Ying C. W. (1991). The History of "Manchukuo". Dalian: Dalian Press.

[5] Du Y. (2009). A comparative analysis between the teacher education of puppet Manchuria and Japan. Century Bridge, (1), 81-82.

[6] Liu G. B. (2007). An investigation of Mongolian ethnic education policy in Manchukuo: Education in Xingan Female National High School. Annals of Educational Research, (53), 40-45.

[7] Shinbo A. (2008). Mongolian female youth education in Manchukuo: Centering on Xin'an Female National High School. East Asian Studies, (50), 3-17.

[8] Nakashima T. (2015). Russian Women's Education in Manchuria: Focusing on Secondary and Higher Education. Ikuta, Michiko (eds.), Manchukuo Women: Living In The Multi-Ethnic Space. Osaka: Ōsaka University Press, 68-87.

[9] Hanai M. (2015). Manchukuo emigrated Korean women: focusing on female education. Ikuta, Michiko (eds.),
Manchukuo Women: Living in the Multi-Ethnic Space. Osaka: Osaka University Press, 254-278.

[10] Cai Y. Q. (2010). Making Shadows of the War: Women's Mobilization in Manchukuo (1932-1945). Taipei: Taipei National History Museum, 99-111.

[11] Wang W. W. (2016). Overall trends of female secondary education in Manchukuo. The Journal of Study on Language and Culture of Korea and China, (22): 91-100.

[12] Wang W. W. (2019). Training national and vocational women: characteristics of curriculum of female secondary education in colonized Manchuria. Asian Journal of Education and Social Studies, 3(3): 1-10.

[13] Wang W. W. (2019). The female images and nationality: examining the Manchukuo moral textbooks "Xiushen" and "Guomin Daode". Annual Report on the Colonial Education History, (21), 42-64.

[14] Wang Y. P. (1989). Fourteen-year Educational History of the Occupied Northeast. Jilin: Jilin Education Press, 22-123.

[15] Fengtian Female Normal School (1926). A general survey of Fengtian female normal school and affiliated primary school. Fengtian: Fengtian Female Normal School, 14.

[16] Fengtian Female Normal School (1926). A general survey of Fengtian female normal school and affiliated primary school. Fengtian: Fengtian Female Normal School, 4.

[17] The Fengtian First Female Secondary School (1933). Embodiments of labor education. Fengtian Education, 1(4), 4-5.

[18] Bai G. T. (1935). Research on female learning and training. Fengtian Education, 2(3), 64.

[19] Liu G. F. (1935). Points for special attention on practices and methods in current Manchukuo female education. Fengtian Education, 2(3), 67.

[20] Nawa (1936). The essence of female education. Fengtian Education, 4(7), 106-109.

[21] Education Department of Northeast Normal University (1951). The slavish education of the "Manchukuo". Changchun: Northeast Normal University Press, 34-36.

[22] Nakamura T. (1938). The fundamentalism of female education. Fengtian Education, 6(2), 61-63.

[23] Satō Y. (1937). The mission of women educators. Fengtian Education, 5(9), 135-137.

[24] Nakano H. (1937). About the Mission of the woman's family. Fengtian Education, 5(9), 140-141.

[25] Ren Z. X. (1941). Female education: the teaching of Manchukuo national high school. Fengtian Education, 7(7), 87.

[26] Minagawa (1937). Principle of new education system, Manzhou Education, 3(6), 2-3.

[27] Hikari Yasuhiro (1943). Education acts in 1942. Kenkoku Education, 9(1), 14. 